九州大学学術情報リポジトリ

Kyushu University Institutional Repository

\title{
Method Development of Measuring Depth of Burn Using Laser Ranging in Laboratory Scale
}

\section{Lasta Azmi llah Akbar}

Department of Mechanical Engineering, Faculty of Engineering, Universitas Indonesia

Dwi Marhaendro Jati Purnomo

Department of Mechanical Engineering, Faculty of Engineering, Universitas Indonesia

Randitia Andika Putra

Department of Mechanical Engineering, Faculty of Engineering, Universitas Indonesia

Raden Bregas Dwi Hatmojo

Department of Mechanical Engineering, Faculty of Engineering, Universitas Indonesia

他

https://doi.org/10.5109/4055231

出版情報 : Evergreen. 7 (2)，pp.268-274，2020-06. 九州大学グリーンテクノロジー研究教育センター バージョン：

権利関係 : 


\title{
Method Development of Measuring Depth of Burn Using Laser Ranging in Laboratory Scale
}

\author{
Lasta Azmillah Akbar ${ }^{1}$, Dwi Marhaendro Jati Purnomo ${ }^{1}$, Randitia Andika Putra ${ }^{1}$, \\ Raden Bregas Dwi Hatmojoํㅜ, Hafizha Mulyasih ${ }^{1}$, Yulianto Sulistyo Nugroho ${ }^{1, a)}$
}

\author{
${ }^{1}$ Department of Mechanical Engineering, Faculty of Engineering, Universitas Indonesia - \\ Indonesia
}

*Author to whom correspondence should be addressed:

E-mail: yulianto.nugroho@ui.ac.id

(Received November 5, 2019; Revised May 2, 2020; accepted May 21, 2020).

\begin{abstract}
Peatland fire releases a huge amount of carbon emissions to the atmosphere causing air pollution and soil damage. The total emission released to the air could be calculated through the amount of peat that burned downor known as depth of the burn. In this research, a device was developed to detectthe smouldering spread of peat both laterally and vertically through the subsidence. The device was operated using a microcontroller and a laser ranging module. This paper presents a preliminary result on the device capability on measuring several objects such as flat surface and semi-spherical objects.
\end{abstract}

Keywords: Laser ranging, Depth of burn, Point clouds image, Microcontroller

\section{Introduction}

Indonesia is a tropical country with the total area of tropical peatland approximately $16.8-27.0$ million ha are found across the country ${ }^{1}$. Peat serves as carbon storage contained a high amount of carbon that can be used by plants that grow above them. Peatland produced in area with high water content, Mutalib et al. said peat water contain could reach $100-1300 \%$ which $1-13$ times of original mass ${ }^{15)}$, so it is unlikely to catch on fire because nearly $90 \%$ is water, because of the change of the environment condition and the works of human peatland become dried up and could easily be caught on fire ${ }^{16)}$. Peat fire gives a huge loss for the environment such as emission of carbon that released. 1997 peatland fire in Indonesia release around $0.19-0.23$ gigatonnes of carbon ${ }^{2)}$. In 2015 the mean emission release around September and October reach the value of $11.9 \times 10^{12}$ gram of $\mathrm{CO}_{2}$ per day ${ }^{12}$.

Emission of carbon that being released by peatland fire can be estimated by the amount of peat that burned because of the fire. Peat fire mostly dominated by smouldering combustion, which is a flameless form of combustion ${ }^{13)}$, different from flaming combustion it has a slow spread rate and could sustain in lower temperature and low oxygen concentration ${ }^{14)}$. Unfortunately, smouldering combustion that happened on peatland could not easily predicted because of several factors such as moisture content ${ }^{9}$, which could have effect on hydrophilic and hydrophobic properties of peat when overdried, these conditions could affect the burning peat ${ }^{6}$. Peat fire also depend on the heat transfer applied on the peat when it caught on fire ${ }^{10)}$, another peat characteristic affect the spread is bulk density ${ }^{11)}$ and components that composed the peat itself that caught on fire.

LIDAR (Light Detection and Ranging) is one of high end remote sensing tool with vast application. The most basic application is to measure distance with high value of measurement ${ }^{18)}$. LIDAR could produced an image of an area that could be use for invetigating landslide ${ }^{20 \& 21)}$ and landslide mapping ${ }^{19)}$ Another use of LIDAR is to measure emission from certain area, this was done using certain wavelength of light ${ }^{24)}$.

A research has been done by U. Ballhorn. using LIDAR to estimate the emission and burn of $\mathrm{scar}^{3}$. The research objective is to measure the peat depth of burnt and estimating the emission produced by knowing the position and the depth of burnt. This concept is similar with measuring the height of vegetation and trees using the tool $^{22)}$. Peat lose some amount of its volume after burned down and leaving a trace of the depth of burnt that can be used to estimate the total burnt down volume, this volume is proportional to emission which has been released to the atmosphere.

Using a similar concept as LIDAR, A device has been developed with the same function which is plotting the contour or the spreading of smouldering with a similar objective as laser scanning ${ }^{23)}$. The measuring component which has been installed for the device works under the 
principle of laser ranging. Laser ranging itself is a measuring instrument used for measure distance of an object. This instrument emits laser and catches it back after being reflected by an object, thus the distance can be measured by the time differences. This device that is developed has advantages such as better precision and more affordable, even though its measuring range is limited for several meters. This device expected to give us a better view of smouldering spread and depth of burn of burning peat. Using an automated system, it could increase the efficiency where a controlled device such as a robot could do works with lesser downtime ${ }^{8)}$.

\section{Materials}

\subsection{Framework and movement mechanism}

The device on this research is going to be used for measuring the smouldering spread on a small scale of a peat fire. It worked on a frame with the dimension of length, wide, height in subsequence is $600 \times 600 \times 1000$ $\mathrm{mm}$ made of aluminum profile with dimension $40 \times 40$ $\mathrm{mm}$, the frame can be seen in figure 1 . The frame serves as the structure for the drive system which is stepper motor with its tracks and servo, also it is used for placing the controller. All of these drive systems and controllers are placed approximately $600 \mathrm{~mm}$ above the ground.

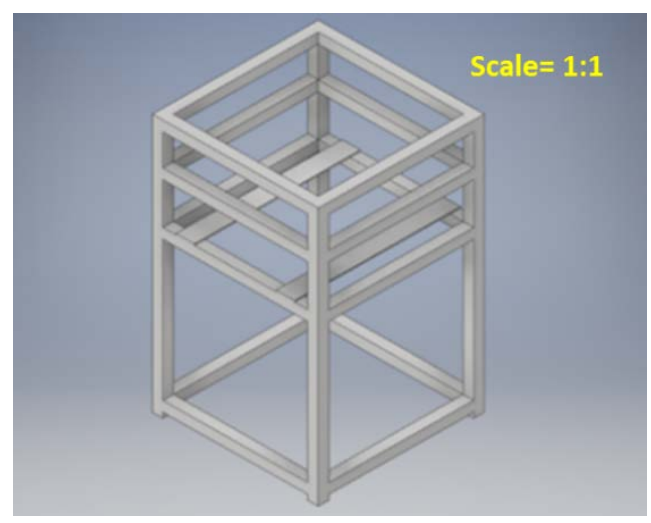

Fig. 1: System frame

The first drive system that has been used for this device is the stepper motor for X-axis. Nema 17 stepper motor is used and connected with a lead screw that already mounted with a bracket for the controller. The movement in the X-axis depends on the rotation that has been done by the stepper motor. In this research, the step motor which has been used has step angle $1.8^{\circ}$ for each step and for full $360^{\circ}$ could move the bracket that contains the controller for $8 \mathrm{~mm}$. Therefore this device uses motor stepper as prime mover due to its resolution. The total distance that can be reached is between $10-300 \mathrm{~mm}$ from stepper bearings, it is due to the size controller bracket.

The second drive system that has been used for this device is the servo. Servo is a motor capable to rotate $180^{\circ}$ and it serves as a rotating motor for the laser mounting that puts on the servo's gear. The purpose of using the servo is the laser could rotate and scan every side of the peat in one line after another that was put on the ground. With both of these drive systems, this device expected could cover every side of the burning peat that is going to be scanned and measured.

\subsection{Controller and data logging}

Laser ranging as known as laser rangefinder has the capability to measure the distance to a high degree of accuracy. The way this instrument works is emitting a pulse of laser to object and catch the reflected laser pulse then calculate the distance using the time required for the emitted laser to reflect on the object and come back to the receiver. The type of laser ranging which has been used on this device is VL53L0X, this component is Time-of-Flight (TOF) laser-ranging module. This type of laser emits a short pulse of laser but intense radiation to travel from the module to the object ${ }^{4}$.

Table 1. VL53L0X Specification ${ }^{5)}$

\begin{tabular}{cc}
\hline Features & Details \\
\hline Size & $4.40 \times 2.40 \times 1.00 \mathrm{~mm}$ \\
Measuring range & $100-2000 \mathrm{~mm}$ \\
Accuracy & $\pm 5 \%$ \\
FoV(Field of View) & $25^{\circ}$ \\
Operating Temperature & $-2070^{\circ} \mathrm{C}$ \\
Resolution & $1 \mathrm{~mm}$ \\
Infrared emitter & $940 \mathrm{~nm}$ \\
\hline
\end{tabular}

According to Table 1 . choosing this component as a measuring system for this research is a better choice since it has an advantage over other measuring components such as better accuracy and measuring range. This component is modified so it is compatible and easily connected with the microcontroller that using the I2C interface using two signals: serial data line (SDA) and a serial clock line $(\mathrm{SCL})^{5}$. Each module connected to the controller has its own unique address with the communication of a master-slave relationship.

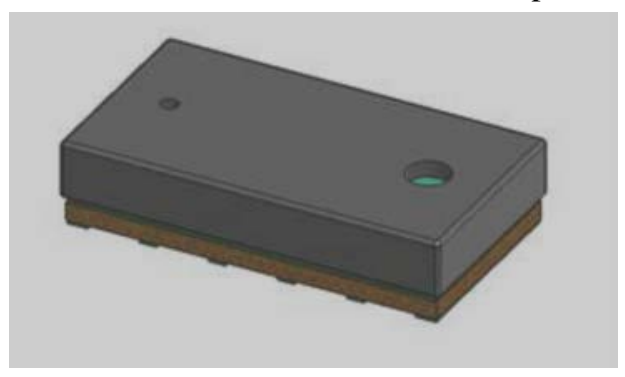

Fig. 2: VL53L0X distance measuring component

Controller and Data LoggerBoth drive system and measuring system are integrated and controlled with a microcontroller. In this research Arduino Mega 2560 is used for integrating all of the component so it works in sequentially. Arduino has the advantage of being easy to understand and easy to change the desired variable. Another reason of using Arduino mega 2560 as controller is the versatile characteristic of Arduino. It has high level 
of compatibility with the module that is used in this research such as VL53L0X laser-ranging module, stepper motor driver, and servo as can be seen on Figure 3. In this research two Arduino Mega 2560 are used for the controller to integrated all of the components and to run the program that had been made before, it is hoped to reduce errors and increasing the processing speed. Both Arduino is connected with I2C connection and a masterslave relationship is created. This connection also used on the TOF laser ranging module.

Arduino also used as a data logger system for recording all kinds of data. In this research Arduino mega with SD card module is used for recording all of the data while the program is being run. The data which are going to be recorded is the distance of peat from VL53L0X, the position of the sensor in the $\mathrm{X}$-axis, the angle of the servo that being run by the program, and the total recorded data. All of the data is saved inside the SD card which connected to Arduino Mega 2560.

This system uses two power source, both are the direct current power source. The first power source is 5 volt with operating current 2 amperes to give power for the microcontroller, this includes power for both laser, servo, and data recorder. The second power source is for the stepper motor and the voltage of the second power source is 24 volt with operating current 1.4 amperes. Approximately the total power used for this device is 43.6 W or $156.96 \mathrm{KW}$ per hour

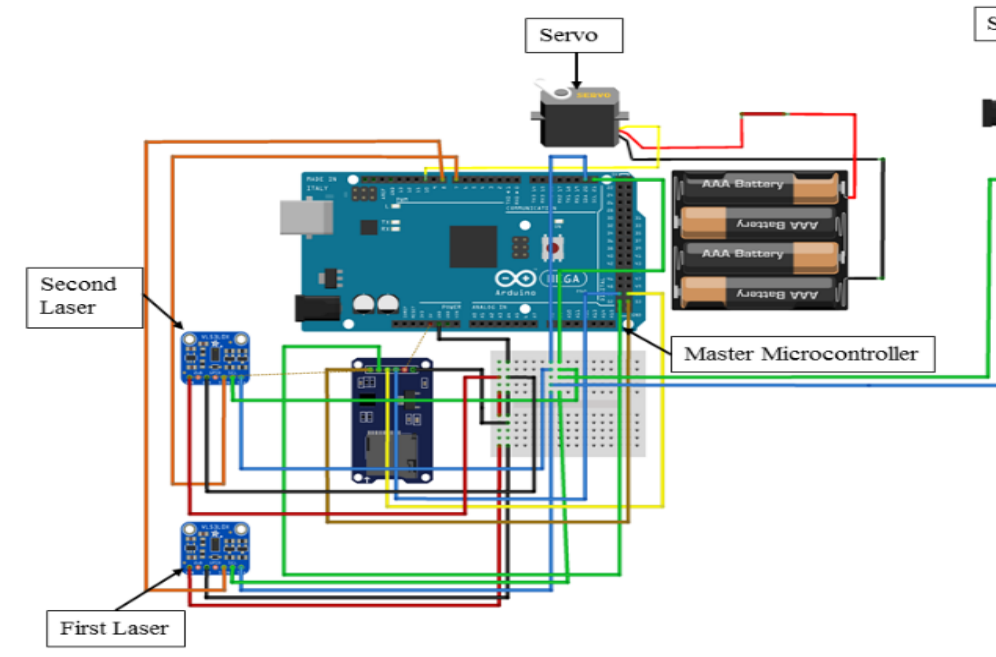

the form of position, angle, and distance must be processed first to the Cartesian diagram or XYZ axis. Data processing is done through the stages of post-processing in the MATLAB program. Data processing is done with simple trigonometry equation and directly plotted to the Cartesian diagram into point clouds ${ }^{17)}$, so it can be measured and compared. The results of this device depend on the time needed to run the program.

\subsection{System validation}

The device that has been designed for measuring the depth of burn has been tested through some validation tests to validate the data. 3 kinds of tests that had been conducted to validate the device are the static test, rotation test, and moving test. All validation test method was done on flat wooden plate. Static test was done with taking a hundred data on same point, it also taken on different depth from the sensor. Rotation test was done by taking data with rotational movement of the servo without moving the stepper motor on $\mathrm{X}$-axis. This test take data from 31 points in one line on $\mathrm{Y}$ axis. Moving test is the opposite of rotation test, data was taken when the stepper was moved without rotational movement of servo.

\section{Results and discussions}

The device that has been designed to use 2 microcontrollers, it has advantage for quicker processing

Fig. 3: System wiring

\subsection{Data collection and serving method}

Device testing is done by measuring various types of objects placed right below the device. This aims to see the level of accuracy of the tool. There are three main data recorded to describe the shape of the object that is under the object. Those three data are the laser position on the $\mathrm{X}$-axis, the servo rotation angle, and the distance between the laser and the object obtained. The three distances in time. This is caused by the program in arduino is done sequentially, it also make the program much longer which cause longer input time and running time. Using 2 Arduino could run 2 programs in parallel in the same, it will cut short run time and processing time.

Validation test has been conducted to validate data that recorded by the device.those 3 tests are static, rotational, and moving test. Each test has different purpose. 
Static test that has been conducted on 5 different depth can be seen on figure 4.(a), the reading value is closer to the actual value when the object is further from the sensor. At the depth of $483 \mathrm{~mm}$, the value recorded is $482.85 \mathrm{~mm}$ while at distance $178 \mathrm{~mm}$ the value is $173.31 \mathrm{~mm}$. This show different point might need different offset value for calibration. For the data that recorded in this research the in which taken in depth of $483 \mathrm{~mm}$ has been calibrated and validated. Rotational test show the straightness of reading value on Y-axis and the accuracy of the servo rotation. On figure 4.(b) shows the data that has been recorded nearly straight with the average of the depth is $482.2 \mathrm{~mm}$. some errors can be seen at the most left and right points of the data, which means the servo and sensor accuracy at those points are worse than the middle. From this test, it is recommended to 173.3take data within range near the middle point in Y-axis. Moving test show the straightness on X-axis, this include the lead screw and stepper motor. On figure 4.(c) shows the reading value has average of $485 \mathrm{~mm}$. the reading value increase as the motor moving, this means there is increment on the position of the driving system in this axis. For depth 483 $\mathrm{mm}$ the data has been validated with these tests. This measurement also depends on the wavelength of the laser used for measurement, where according to Haiya Yang and Akira Harata where shorter wavelength could hit smaller object more easily ${ }^{7}$.

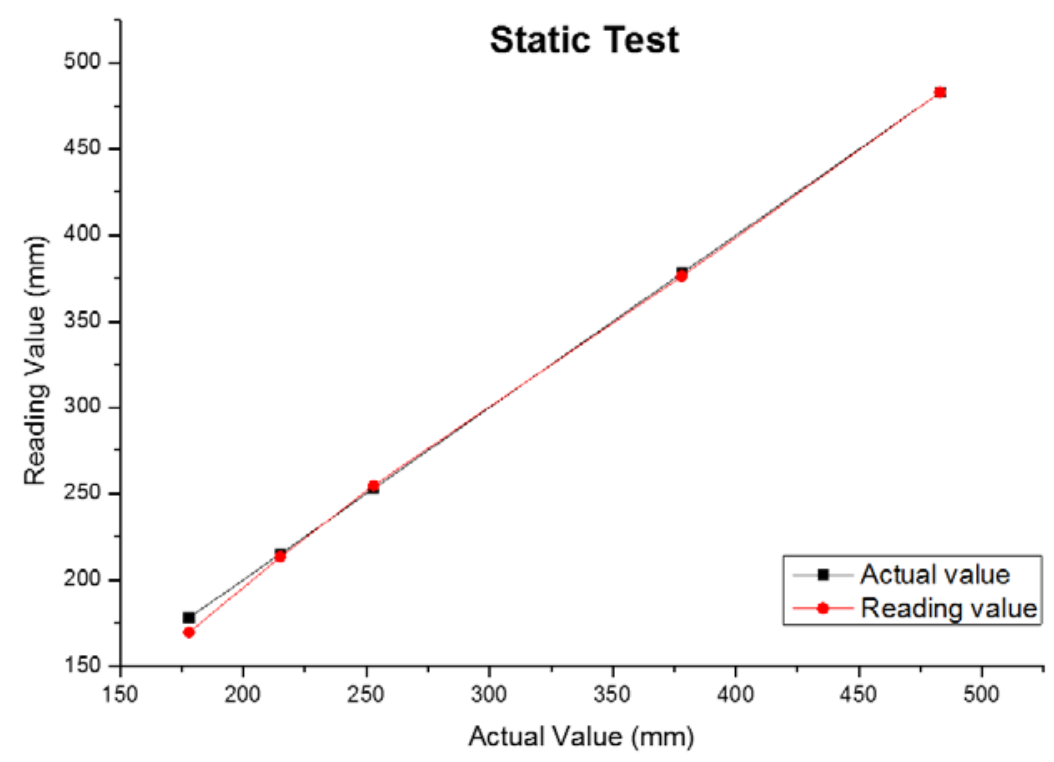

(a)

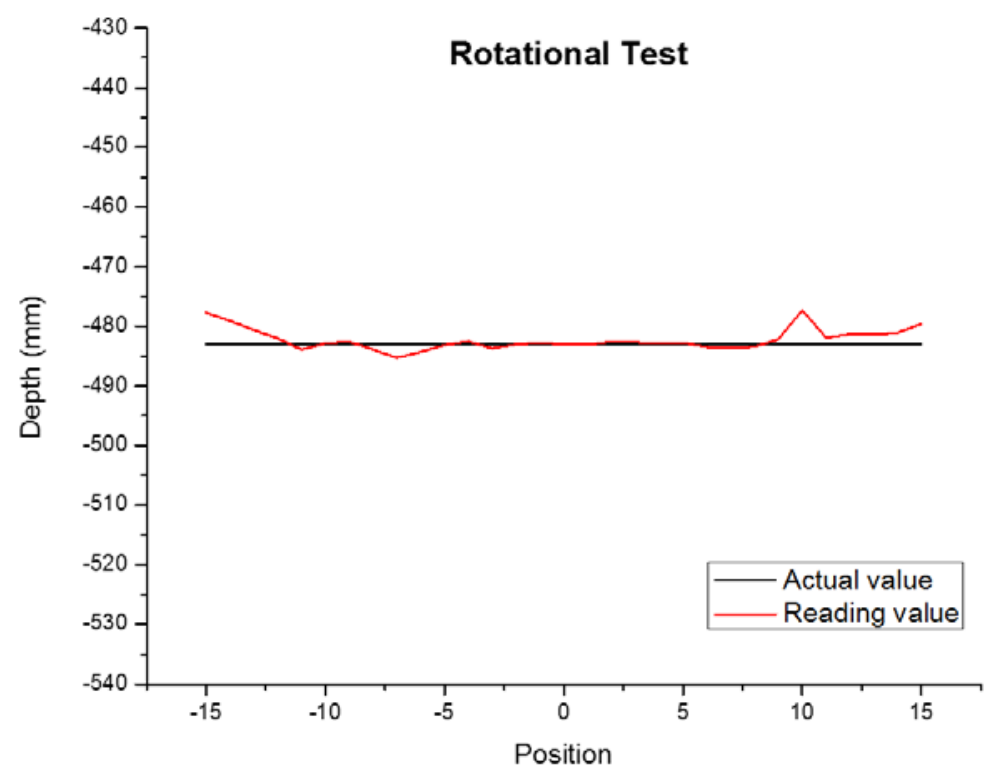

(b) 


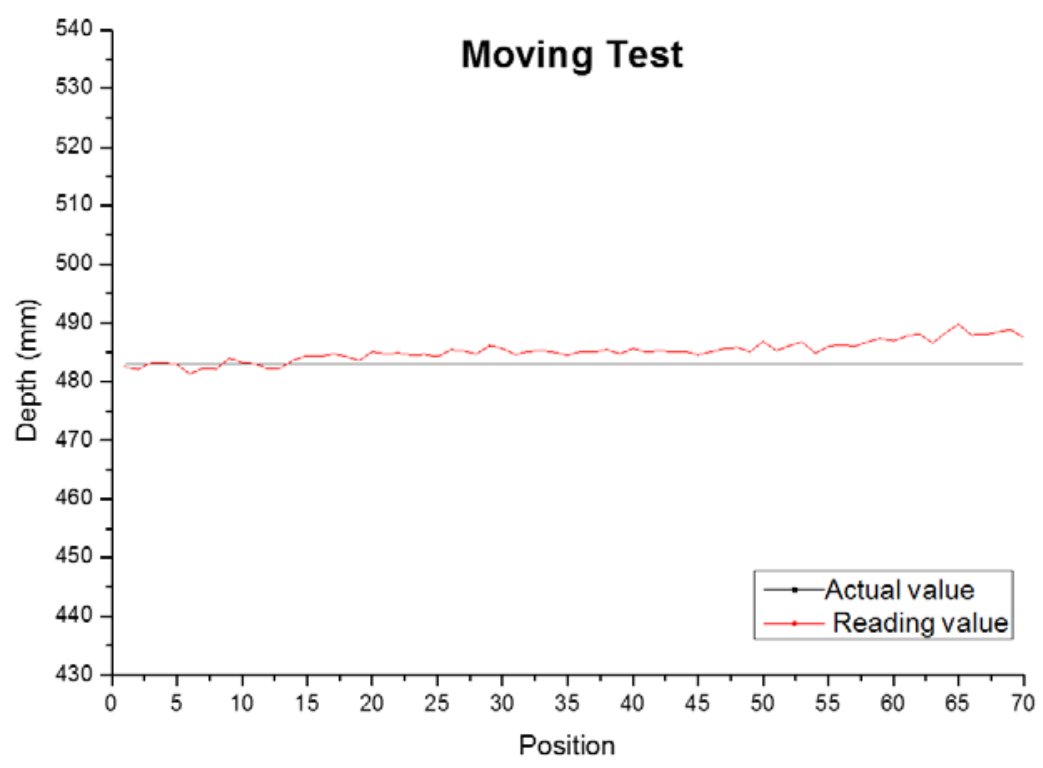

(c)

Fig. 4: (a) static test, (b) Rotational test, (c) Moving test

Device testing was carried out on two objects: flat surface and semi-spherical object. both tests carried out are used to compare the characteristics of the two objects. Both objects have different distances between objects and sensors. The experiment on flat plate aims to see the accuracy of the device and the experiment on semi spherical object aims to see the change of distance between object and the laser ranging module.

Flat wooden plate measuring experiment is conducted with the position of the plate approximately $483 \mathrm{~mm}$ under the laser ranging module. As can be seen at Figure 5. The distance measured have range between $465-500 \mathrm{~mm}$ under the laser ranging sensor. The depth of flat plate that have been measured is in accuracy range which is $5 \%$ as seen on Table 1 . The time needed to take data is approximately 30 minutes. In 15 minutes only half data was taken, although the result would not be have many differences because the object is flat.

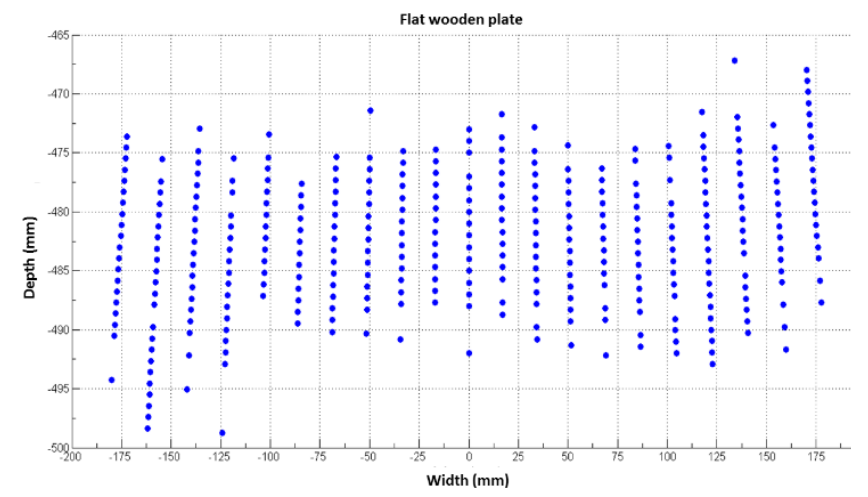

(a)

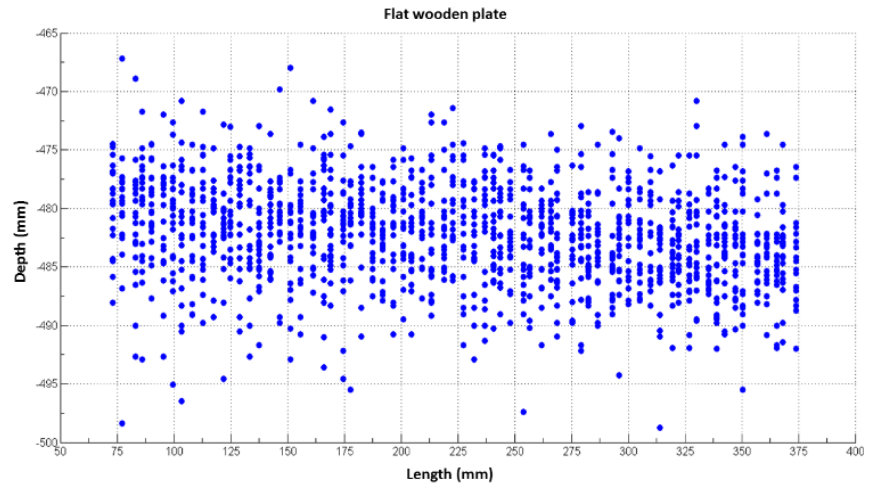

(b)

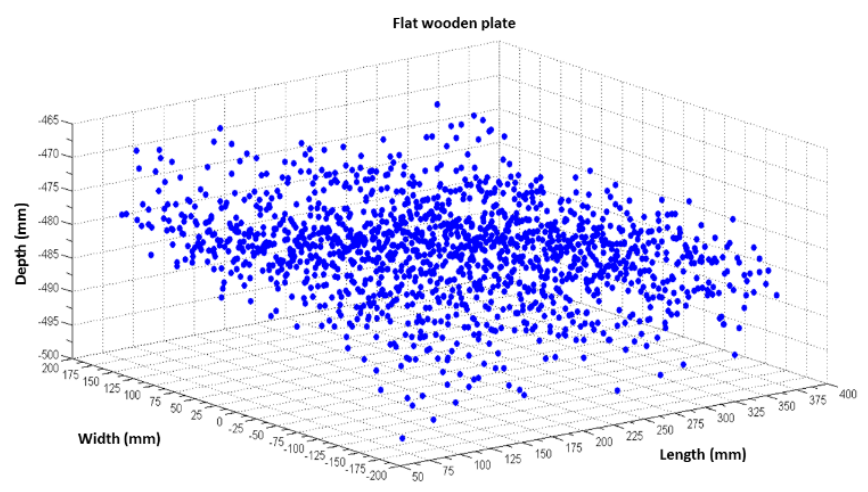

(c)

Fig. 5: (a) Front view of flat plate measuring test result, (b) Side view of measuring test result, (c) Isometric view of measuring test result 


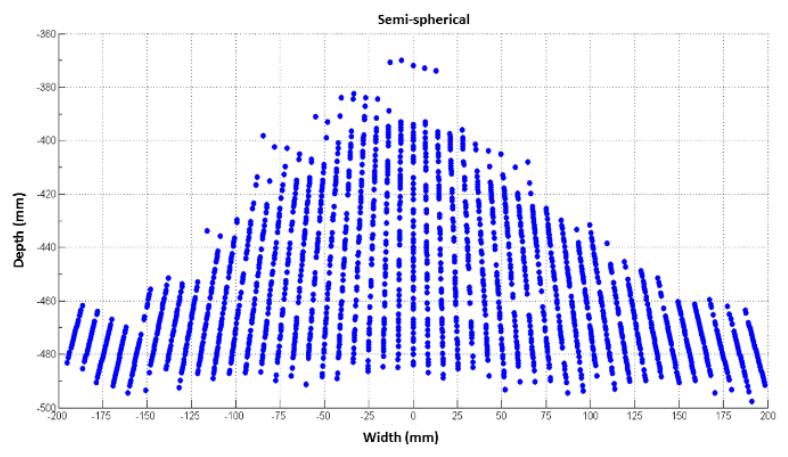

(a)

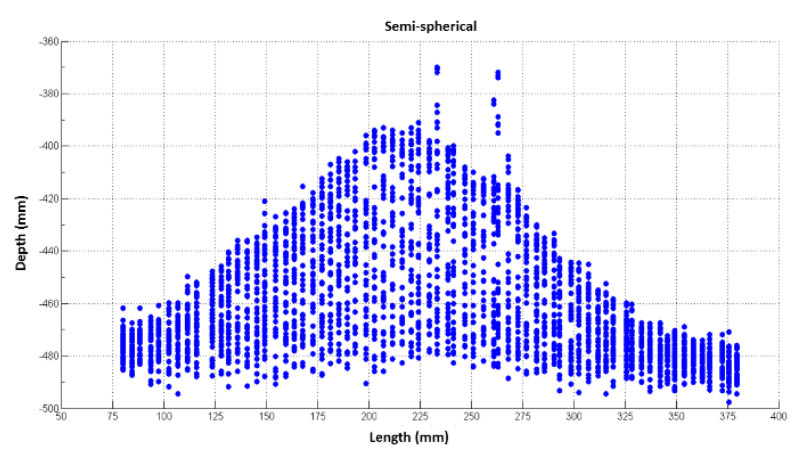

(b)

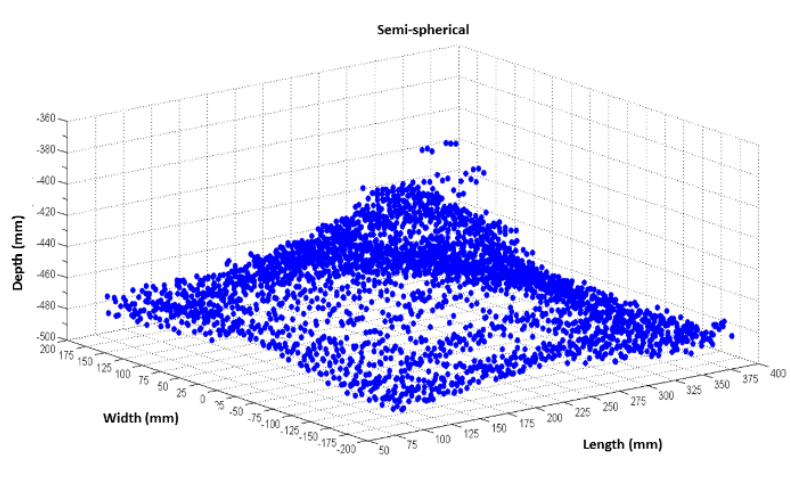

(c)

Fig. 6: (a) Front view of semi-spherical measuring test result, (b) Side view of measuring test result, (c) Isometric view of measuring test result

The measuring test conducted on semi-spherical object with flat top made of plastic is placed near the measuring range. The object has a height of $110 \mathrm{~mm}$ and a diameter of $200 \mathrm{~mm}$. The distance of the object is approximately $375 \mathrm{~mm}$ from the object The measuring test result in Figure 6. shows the distance of the nearest points is around 390 - $410 \mathrm{~mm}$ below the sensors and it caught the radius of the base around $110 \mathrm{~mm}$. These values are still in the accuracy range of the measuring module, though it is not as accurate as of the flat wooden plate measurement, as seen from the reading value where only in $+5 \%$ accuracy range. These werecaused by the material of object used for measurement, laser reflection are affected by some factors such as the color, roughness, and material ${ }^{25)}$. The point clouds image recorded also could illustrate the object shape with its features. This test was done within 30 minutes of cycle time, 10 minutes of the cycle time takes the data of the flat under the spherical, then take data for the semi-spherical object in the rest of full cycle time. At 20 minutes, the data that has been taken is around top of the object.

Similar research on bigger scale by U. Ballhorn using LIDAR on peatland in Borneo and the area is 2.acres. The measurement using this method showed the depth of burnt was $0.33 \pm 0.18 \mathrm{~m}$. From this research shows using this laser ranging sensor for measuring depth of burn has better accuracy for smaller scale rather than bigger scale sensor such as LIDAR, this has been proofed by the value of depth reading from both objects.

\section{Conclusion}

The device that has been developed could detect an object and measure the distance of the object below the device for creating point clouds image as intended on the object. Where for flat plate experiment could measure, creating proper point clouds, and detect the flatness of the plate with the value $465-500 \mathrm{~mm}$ within the accuracy range of the laser ranging module which is $5 \%$. The device developed also could detect the existence of the object with the shape of semi-spherical with flat top surface with the value of measurement approach the real dimension of the object. Though it has less accuracy caused by the material of the object. From this experiment it can be concluded that the device could measure and describe the object below it. Through these results, it can be seen that this device could measure the distance and illustrate objects within the accuracy range. So this device could be implemented for measuring the subsidence of the smouldering peat. Thus, the spread rate of smouldering combustion can be calculated and the subsidence of the peat can be illustrated.

\section{Acknowledgments}

The authors would like to thank Universitas Indonesia for the financial assistance through Hibah Publikasi Internasional Terindeks PIT_9 funding scheme with a contract number. NKB-0085/UN2.R3.1/HKP.05.00/2019 managed by the Directorate for Research and Public Services (DRPM) Universitas Indonesia.

\section{Reference}

1) Page, S. E., Banks, C. J., Rieley, J. O.. Tropical peatlands: distribution, extent and carbon storage uncertainties and knowledge gaps. Peatlands International. 2, 26 - 27. (2007)

2) Page, S. E., Siegert, F., Rieley, J. O., Boehm, H.-D. V., Jaya, A., \& Limin, S.. The amount of carbon 
released from peat and forest fires in Indonesia during 1997. Nature, 420, 61-65. (2002)

3) Ballhorn, U., Siegert, F., Mason, M., \& Limin, S.. Derivation of burn scar depths and estimation of carbon emissions with LIDAR in Indonesian peatlands. Proceedings of the National Academy of Sciences. 106, 2. (2009)

4) Shan, J., Charles, K.Toth, , Topographic Laser Ranging and Scanning: principles and processing, Boca Raton, Taylor\&Francis Group, LLC (2018)

5) STMicroelectronics, Vl53L0X Datasheet production data

6) Ramadhan, M. L., Palamba, P., Imran, F. A., Kosasih, E. A., \& Nugroho, Y. S.. Experimental study of the effect of water spray on the spread of smoldering in Indonesian peat fires. Fire Safety Journal, 91, 671679. (2017)

7) H. Yang, A. Harata, Design of a Semi-confocal Fluorescence Microscope for Observing Excitation Spectrum of Soulble Molecules Adsorbed at the Air/ Water Interface. Evergreen joint journal, 2, 1 - 4 (2015)

8) T. Pennapa. Accident of Thai Industry between 2001 and 2017. Evergreen joint journal, 5, 86 - 92 (2018)

9) Frandsen, W. H. Ignition probability of organic soils. Canadian Journal of Forest Research, 27, 1471-1477. (1997)

10) Ohlemiller, T. J. Modeling of smoldering combustion propagation. Progress in . Energy and Combustion Science. 11, 277-310 (1985).

11) Dikici, H., \& Yilmaz, C. H. Peat Fire Effects on Some Properties of an Artificially Drained Peatland. Journal of Environment Quality. 35, 866-870. (2006).

12) Huijnen, V., Wooster, M. J., Kaiser, J. W., Gaveau, D. L. A., Flemming, J., Parrington, M., van Weele, M.. Fire carbon emissions over maritime southeast Asia in 2015 largest since 1997. Scientific Reports, 6, $1-8,(2016)$

13) Rein, G. " Fire Phenomena in the Earth System: An Interdisciplinary Approach to Fire Science” (ed. Belcher, C.) Wiley, 2013. 15-34

14) Belcher, C. M., Yearsley, J. M., Hadden, R. M., McElwain, J. C., \& Rein, G.. Baseline intrinsic flammability of Earth's ecosystems estimated from paleoatmospheric oxygen over the past 350 million years. Proceedings of the National Academy of Sciences, 107, 22448-22453. (2010)

15) Mutalib, A.A, J.S. Lim, M.H. Wong, and L. Koonvai. Characterization, distribution and utilization of peat in Malaysia. Proceeding of the International Symposium on Tropical Peatland. 6-10 May 1991, Kuching, Serawak, Malaysia.

16) Turetsky, M. R., Benscoter, B., Page, S., Rein, G., van der Werf, G. R., \& Watts, A. (2015). Global vulnerability of peatlands to fire and carbon loss. Nature Geoscience, 8, 11-14. (2015)
17) Akca, Devrim. Full automatic registration of laser scanner point clouds. ETH Zurich, (2003)

18) Piracha, M. U., Nguyen, D., Mandridis, D., Yilmaz, T., Ozdur, I., Ozharar, S., \& Delfyett, P. J. Range resolved lidar for long distance ranging with submillimeter resolution. Optics Express, 18(7), (2010)

19) Eeckhaut, M. V. D., Poesen, J., Verstraeten, G., Vanacker, V., Nyssen, J., Moeyersons, J., Beek, L. P. H. V., Vandekerckhove, L. Use of LIDAR-derived images for mapping old landslides under forest. Earth Surface Processes and Landforms, 32(5), 754-769. (2007)

20) Jaboyedoff, M., Oppikofer, T., Abellán, A., Derron, M.-H., Loye, A., Metzger, R., \& Pedrazzini, A. Use of LIDAR in landslide investigations: a review. Natural Hazards, 61(1), 5-28. (2010)

21) Du, J.-C., \& Teng, H.-C. 3D laser scanning and GPS technology for landslide earthwork volume estimation. Automation in Construction, 16(5), 657663. (2007)

22) Suárez, J. C., Ontiveros, C., Smith, S., \& Snape, S. Use of airborne LiDAR and aerial photography in the estimation of individual tree heights in forestry. Computers \& Geosciences, 31(2), 253-262.

23) Wulf, O., \& Wagner, B. Fast 3D scanning methods for laser measurement systems. International conference on control systems and computer science (CSCS14), 2-5. (2003)

24) Beniston, M., Wolf, J. P., Beniston-Rebetez, M., Kölsch, H. J., Rairoux, P., \& Wöste, L. Use of lidar measurements and numerical models in air pollution research. Journal of Geophysical Research: Atmospheres, 95(D7), 9879-9894. (1990).

25) Lichti, D. D., \& Harvey, B. R. (2002). The effects of reflecting surface material properties on time-offlight laser scanner measurements. Symposium on Geospatial Theory, Processing and Application tc, 2, 1 - 9. (2002) 